\title{
BUDIDAYA IKAN LELE SANGKURIANG DENGAN SISTEM BIOFLOK DI DESA JERUKLEUEUT KECAMATAN SINDANGWANGI KABUPATEN MAJALENGKA
}

\author{
Aden Arif Gaffar, Abdur Rasyid, Yeni Suryaningsih \\ Universitas Majalengka, Indonesia \\ adenarif@unma.ac.id
}

\begin{abstract}
Freshwater fish commodity such as catfish is one of the quite high market demands. Catfish farming is carried out in the village of jerukleueut Sindangwangi Majalengka Regency. The purpose of this activity is to increase the knowledge and production of catfish by using a biofloc system. Catfish cultivation with a biofloc system is one of the systems by utilizing its microorganisms that are useful as additional food in the form of lumps of various types of organisms such as fungi, bacteria, algae, protozoa, worms, and others. Catfish seedlings with a biofloc method with an initial weight of an average of 3.29 grams and a length of $7.3 \mathrm{~cm}$ and after being maintained for 40 days have an average weight of 12.35 grams and an average length of $13.1 \mathrm{~cm}$. The increase in weight experienced was $9.06 \mathrm{grams}$ and an increase in length of 5.8 $\mathrm{cm}$. Meanwhile, in media without biofloc, catfish seeds which have an average initial weight of 3.10 grams and a length of $7.3 \mathrm{~cm}$, after 40 days there was an increase to 9.75 grams and a length of $11.5 \mathrm{~cm}$. Thus an increase in weight reached $6.65 \mathrm{grams}$ and an increase in length of $4.2 \mathrm{~cm}$.
\end{abstract}

Keywords; biofloc; catfish; growth; media

\begin{abstract}
Abstrak
Komodias ikan air tawar seperti ikan lele salah satu permintaan pasar yang cukup ringgi. Budidaya ikan lele dilakukan di desa jerukleueut Sindangwangi Kabupaten Majalengka. Tujuan dari kegiatan ini untuk meningkatkan pengetahuan dan produksi ikan lele dengan menggunakan sistem bioflok. Budidaya ikan lele dengan sistem bioflok merupakan salah satu sistem dengan memanfaatkan mikroorganisme didalmnya yang bermanfaat sebagai makan tambahan berupa gumpalan berbagai jenis organisme seperti jamur, bakteri, algae, protozoa, cacing, dan lain lain. Benih ikan lele dengan metode bioflok bobot awal rata-rata 3,29 gram dan panjang $7,3 \mathrm{~cm}$ dan setelah dipelihara 40 hari memiliki berat rata-rata 12,35 gram dan panjang rata-rata $13,1 \mathrm{~cm}$. Peningkatan berat yang dialami yaitu 9,06 gram dan peningkatan panjang $5,8 \mathrm{~cm}$. Sementara itu, pada media tanpa bioflok, benih lele yang memiliki berat awal rata-rata 3,10 gram dan panjang $7,3 \mathrm{~cm}$, setelah 40 hari terjadi peningkatan menjadi 9,75 gram dan panjang $11,5 \mathrm{~cm}$. Dengan demikian terjadi peningkatan berat mencapai 6,65 gram dan peningkatan panjang 4,2 cm.
\end{abstract}

Kata Kunci: bioflok; ikan lele; pertumbuhan; media

\begin{tabular}{l|l|l} 
Submitted: $2020-06-17$ & Revised: $2020-07-13$ & Accepted: $2020-07-17$
\end{tabular}

\section{Pendahuluan}

Sindangwangi adalah sebuah kecamatan di Kabupaten Majalengka, Provinsi Jawa Barat, Indonesia. Di lihat dari topografi dan kontur tanah Kecamatan Sindangwangi secara umum berupa darat dan sawah yang berada pada ketinggian antara 30 sampai dengan 42 meter diatas permukaan laut, dengan suhu rata-rata berkisar antara 24 sampai dengan 29 derajat celcius. Memperhatikan potensi wilayah dan sesuai dengan permasalahan terkait realisasi RPJM di wilayah Desa Jerukleueut disepakati programprogram prioritas yang dilaksanakan salah satunya adalah budidaya ikan lele. 
Produksi ikan lele menurut Badan Pusat Statistik di Kabupaten Majalengka Tahun 2019, dari total 26 kecamatan, kecamatan Sindangwangi hanya menghasilkan 0,44 ton/ tahun. Permasalahan yang sangat mendasar dalam budidaya ikan lele yang dilakukan selama ini budidaya dikembangkan secara konvesional, pembuatan kolam, pengolahan air, pembesaran bibit dan pakan lele, serta hanya sebatas penjualan bibit bukan budidaya dikarenakan metode budidaya yang dilakukan dengan menggunakan metode konvesional selama ini membutuhakan biaya yang besar dan waktu yang cukup lama, sedangkan ikan lele yang dihasilkan tidak melimpah. Produksi ikan yang dihasilkan dengan menggunakan metode konvensional seperti seleksi induk, transfer gen (transgenesis), dan protein rekombinan tidak memenuhi target. Dengan meningkatnya permintaan pasar sekitar $79 \%$ tidak mencukupi ikan lele yang dihasilkan melalui metode konvesional. Ada beberapa cara teknologi budidaya ikan lele yang dilakukan untuk meningkatkan produksi ikan lele salah satunya adalah metode Bioflok. Metode bioflok dalam meningkatkan produksi dan kualiats ikan lele. Nadya Adharani dkk (2016) mendapatkan bahwa metode bioflok dapat memperbaiki kualitas air yang dilihat dari penuruan konsentrasi parameter TAN, amoniak, nitrit dan nitrat. Metode bioflok adalah salah satu metode alternatif dalam menyelesaikan masalah kualitas air buangandalam budidaya ikan lele. Bioflok berasal dari kata bios yang artinya kehidupan dan flock yang bermakna gumpalan, sehingga bioflok adalah kumpulan dari berbagai jenis organisme seperti jamur, bakteri, algae, protozoa, cacing, dan lain lain, yang tergabung dalam gumpalan. Teknologi bioflok atau lumpur aktif merupakan adopsi dari teknologi pengolahan biologis air limbah lumpur aktif dengan menggunakan aktivitas mikroorganisme untuk meningkatkan carbon dan nitrogen (Suprapto, 2013). Terbatasnya sumber daya alam seperti air dan lahan, menjadikan intensifikasi sebagai pilihan yang paling memungkinkan dalam meningkatkan produksi budidaya. Berbagai upaya untuk mengembangkan perikanan budidaya terutama pada sistem intensif hingga kini masih terus dilakukan mengingat sistem tersebut masih terkendala oleh berbagai masalah di antaranya buangan limbah akuakultur.

Mikroorganisme yang dilibatkan dalam sistem bioflok adalah bakteri Salah satu bakteri yang ada dalam metode bioflok adalah jenis Bacillus (Aiyushirota, 2009). Menurut Avnimelech, (1999) penambahan materi karbon bakteri heteretof dapat mengubah nitrogen anorganik yang berasal dari feses dan pakan menjadi protein sel tunggal sehingga dapat dimanfaatkan menjadi sumber pakan bagi ikan. Metode bioflok digunakan dalam kegiatan ini bertujuan untuk mengurangi penggunaan air dalam budidaya ikan lele, mengurangi pembuangan air kelingkungan serta untuk meningkatkan produktifitas ikan lele yang dihasilkan oleh para peternak lele.

\section{Metode}

Kolam terpal dibuat dengan rangka papan dan bagian dalam rangka dilapisi dengan kemudian dilapisi dengan terpal plastik. Sementara itu, pembuatan kolam baru untuk pendederan lele dengan mengaplikasikan bioflok, diawali dengan kolam terpal diisi air hingga penuh kemudian diberi desinfektan (kalium permanganat) dan dibiarkan selama semalam. Hari berikutnya, larutan desinfektan dalam kolam dibuang, kemudian kolam diisi dengan air bersih sebanyak $50 \%$ dari kolam. Ke dalam kolam ditambahkan $50 \mathrm{ml}$ probiotik EM4 dan $250 \mathrm{ml}$ tetes tebu, air kolam dibiarkan selama seminggu tanpa aerasi 
agar terjadi fermentasi. Lima belas hari kemudian, benih ikan lele yang berumur 10 hari dimasukkan ke dalam kolam tersebut. Benih yang ditebar sebanyak 500 ekor per kolam. Selain membuat media budidaya yang baru, dibuat pula kultur probiotik terfermentasi, yang akan dipergunakan untuk memelihara media pemeliharaan dan penyediaan pakan alami.

Kultur probiotik dibuat di dalam jerigen plastik $10 \mathrm{~L}$ dengan cara mengisi jerigen dengan air sebanyak 3L ditambah tetes tebu $2 \mathrm{~L}$ dan EM4 1L. Jerigen kemudian ditutup rapat agar tidak terkontaminasi. Larutan dalam jerigen dibiarkan selama satu minggu agar terjadi fermentasi sempurna. Cara penggunaan larutan tersebut adalah dengan meneteskan setiap hari ke dalam kolam pendederan, sebanyak 10 tetes. Proses pembuatan dan pemeliharaan benih ikan lele dilakukan dari bulan Maret-Mei 2020. Pakan diberikan sebanyak 5\%. Pemberian pakan dilakukan berdasarkan hasil pengukuran bobot sampel dan mortalitas ikan yang dilakukan secara berulang setiap 7 hari. Frekuensi pemberian pakan adalah 2 kali sehari, yaitu pada pagi dan sore hari. Pengamatan kualitas air dan pertumbuhan ikan dilakukan setiap 2 minggu sekali. Pertumbuhan yang diamati adalah pertumbuhan mutlak, yang meliputi panjang dan berat tubuh. Panjang mutlak adalah ukuran rata-rata organisme pada umur tertentu (Effendi, 2003).

Parameter fisik yang diamati adalah temperatur air dan udara, yang diukur dengan termometer alkohol. Parameter kimia yang diamati adalah indeks keasaman $(\mathrm{pH})$ air diukur dengan kertas pH universal. Data yang diperoleh dianalisis secara deskriptif.

\section{Hasil dan Pembahasan}

Pemeliharaan benih ikan lele Sangkuriang yang dilakukan di Desa Jerukleueut Kecamatan Sindangwangi Kabupaten Majalengka, telah dilakukan dalam kolam terpal selama 30 hari dengan menerapkan teknik bioflok. Selama masa pemeliharaan dilakukan pengamatan dan pengukuran pertumbuhan serta kualitas media pemeliharaan, pada hari ke-0, ke-15 dan ke-40. Hasil pengukuran panjang dan berat tubuh ratarata benih ikan lele selama pemeliharaan terangkum pada Tabel 1.

Tabel 1

Pertumbuhan benih ikan lele

\begin{tabular}{ccccc}
\hline \multirow{2}{*}{$\begin{array}{c}\text { Pengamatan } \\
\text { Ke }\end{array}$} & Panjang $(\mathrm{cm})$ & Berat $(\mathrm{g})$ & Panjang $(\mathrm{cm})$ & Berat $(\mathrm{g})$ \\
\hline 1 & 7,3 & 3,20 & 7,3 & 3,10 \\
2 & 9,7 & 4,66 & 8,2 & 3,98 \\
3 & 13,1 & 12,35 & 11,5 & 9,75 \\
\hline
\end{tabular}

Proses Pemeliharaan benih ikan lele sangkuriang yang dilakukan di Desa Jerukleueut menunjukkan hasil yang cukup baik. Secara umum, benih yang dipelihara dengan sistem bioflok mengalami pertumbuhan yang lebih baik dibandingkan yang tanpa bioflok. Hal itu ditunjukkan dengan adanya perbedaan pertambahan panjang maupun berat tubuh yang dialami oleh benih lele pada tiap periode pengamatan.

Sementara itu hasil pengukuran kualitas media pemeliharaan juga menunjukkan adanya perbedaan. Secara lengkap hasil pengukuran parameter fisik-kimia media budidaya tertera pada Tabel 2 berikut. 
Tabel 2

Kualitas media pemeliharaan benih ikan lele

\begin{tabular}{lcc}
\hline \multicolumn{1}{c}{ Parameter Pengamatan } & Bioflok & Non Bioflok \\
\hline Temperatur Air $\left({ }^{\circ} \mathrm{C}\right)$ & $22-26$ & $22-28$ \\
Temperatur Udara $\left({ }^{\circ} \mathrm{C}\right)$ & $26-30$ & $26-30$ \\
$\mathrm{pH}$ & $6-7$ & $6-8$ \\
\hline
\end{tabular}

Hasil pengukuran kualitas fisik-kimia pada media pemeliharaan benih lele di Desa Jerukleueut Kecamatan Sindangwangi. Secara umum dapat dikatakan bahwa media pemeliharaan yang mengaplikasikan teknik bioflok menunjukkan kondisi yang lebih baik dan relatif ideal untuk tumbuh dan kembang ikan lele. Hal ini juga diperkuat dengan relatif rendahnya tingkat kematian benih selama pemeliharaan, yaitu sebesar $12 \%$ dengan faktor kematian tertinggi di akibatkan oleh suhu ekstrim yang terjadi di awal penebaran benih ikan lele.

Benih ikan lele sangkuriang umur 50 hari yang dipelihara selama 40 hari mengalami pertumbuhan dengan pertambahan panjang dan berat tubuh yang bervariasi. Namun, benih lele yang dipelihara dengan aplikasi bioflok, hasilnya relatif lebih baik. Hal demikan dapat diketahui dari pertumbuhan yang dialami oleh benih lele. Benih lele dengan metode bioflok bobot awal rata-rata 3,29 gram dan panjang 7,3 cm dan setelah dipelihara 40 hari memiliki berat rata-rata 12,35 gram dan panjang rata-rata $13,1 \mathrm{~cm}$. Peningkatan berat yang dialami yaitu 9,06 gram dan peningkatan panjang $5,8 \mathrm{~cm}$. Sementara itu, pada media tanpa bioflok, benih lele yang memiliki berat awal rata-rata 3,10 gram dan panjang 7,3 cm, setelah 40 hari terjadi peningkatan menjadi 9,75 gram dan panjang $11,5 \mathrm{~cm}$. Dengan demikian terjadi peningkatan berat mencapai 6,65 gram dan peningkatan panjang 4,2 cm.

Menurut Schryver et al. (2008) bahwa teknologi bioflok adalah suatu sistem budiday abakteri heterotrof dan alga dalam suatu gumpalan floks secara terkontrol dalam suatu budidaya atau merupakan suatu sistem yang memanipulasi kepadatan dan aktivitas mikroba sebagai suatu cara mengontrol kualitas air dengan mentransformasikan amonium menjadi proteimikrobial agar mampu mengurangi residu dari sisapakan (Avnimelech \& Kochba. 2009). Teknikbioflok bertujuan meningkatkan efisien pemanfaatan pakan dengan pembentukan biomassa mikroba makroagregat dari bahan organik dan senyawa terlarut (Serfling 2006).

Pembudidayaan ikan lele dengan menggunakan metode bioflok memberikan keuntungan yang lebih banyak dari metode konvesional. Dapat dilihat dari kapasitas tebar bibit lele yang lebih banyak 20 kali dari konvensional (Suparno, 2016).

\section{Kesimpulan}

Budidaya ikan lele dengan menggunakan metode bioflok memberikan manfaat yang sangat besar bagi peternak lele dan memberikan hasil yang cukup signifikan, penerapan teknologi bioflok memberikan pengaruh yang lebih baik terhadap peningkatan pertumbuhan benih lele serta stabilitas media. 


\section{Daftar Pustaka}

Adharani, N., Soewardi, K., Syakti, A. D., \& Hariyadi, S. (2016). Manajemen Kualitas Air Dengan Teknologi Bioflok: Studi Kasus Pemeliharan Ikan Lele (Clarias Sp.). Jurnal Ilmu Pertanian Indonesia, 21(1), 35-40.

Avnimelech, Y. (1999). Carbon/nitrogen ratio as a control element in aquaculture systems. Aquaculture, 176(3-4), 227-235.

Aiyushirota, I. (2009). Konsep Budidaya Udang Sistem Bakteri Heterotrop Dengan Bioflocs. Aiyushirotabiota, Indonesia.

Badan Pusat Stastistik Kabupaten Majalengka. (2019). Banyaknya Produksi Ikan Lele Menurut Kecamatan di Kabupaten Majalengka Tahun 2019 (Ton)

Effendi MI. 2003. Biologi Perikanan. Bandung: Yayasan Pustakan Nusantara.

Ekasari, J. (2008). Bioflocs technology: the effect of different carbon source, salinity and the addition of probiotics on the primary nutritional value of the bioflocs. Gent (BE). Universiteit Ghent.

Suprapto, S. S., \& Samtafsir, L. S. (2013). Biofloc-165 rahasia sukses teknologi budidaya lele. Depok (ID): Agro, 165.

Suparno, S., \& Qosim, M. (2016). PENGARUH PENGEMBANGBIAKAN BIOFLOK PADA PENINGKATAN PRODUKSI DAN KUALITAS IKAN LELE. Inisiasi, 5(1). 